\title{
Fanning the Flames or a Troubling Truth? The Politics of Comparison in the Israel-Palestine Conflict
}

DOI:

10.1080/13698249.2019.1642612

\section{Document Version}

Accepted author manuscript

Link to publication record in Manchester Research Explorer

\section{Citation for published version (APA):}

Turner, M. (2019). Fanning the Flames or a Troubling Truth? The Politics of Comparison in the Israel-Palestine Conflict. Civil Wars, 21(4), 489-513. https://doi.org/10.1080/13698249.2019.1642612

\section{Published in:}

Civil Wars

\section{Citing this paper}

Please note that where the full-text provided on Manchester Research Explorer is the Author Accepted Manuscript or Proof version this may differ from the final Published version. If citing, it is advised that you check and use the publisher's definitive version.

\section{General rights}

Copyright and moral rights for the publications made accessible in the Research Explorer are retained by the authors and/or other copyright owners and it is a condition of accessing publications that users recognise and abide by the legal requirements associated with these rights.

\section{Takedown policy}

If you believe that this document breaches copyright please refer to the University of Manchester's Takedown Procedures [http://man.ac.uk/04Y6Bo] or contact uml.scholarlycommunications@manchester.ac.uk providing relevant details, so we can investigate your claim.

\section{OPEN ACCESS}




\title{
Fanning the Flames or a Troubling Truth? The Politics of Comparison in the Israel-Palestine Conflict
}

\author{
Mandy Turner ${ }^{1}$
}

The politics of comparison in the Israel-Palestine conflict is largely encapsulated in the use of two analogies. The first is the 'HolocaustHitler analogy' used by Israel and its supporters, which portrays Israel as a beleaguered nation surrounded by Nazi sympathisers who seek to destroy it as the Jewish homeland. The second is the 'apartheid analogy', which compares the conflict to that of Apartheid-era South Africa and portrays Palestinians as being the victims of racism and settler colonialism. This article analyses why, how and with what desired impact these two comparisons are invoked.

Keywords: Israel-Palestine conflict; conflict comparisons; analogies and metaphors; Holocaust metaphor; apartheid analogy; critical realism

On 30 September 2015, Palestinian Authority President Mahmoud Abbas addressed the UN General Assembly in New York. He warned that Israel was imposing an "apartheid regime" in the occupied territory - with one legal and governance system for Palestinians, and another for Jewish-Israeli settlers (Times of Israel, 30 September 2015). US State Department spokesperson Jen Psaki described the speech as "provocative" and "counterproductive", including "offensive characterizations that were deeply disappointing and which we reject" (Times of Israel and AFP, 27 September 2015). Unsurprisingly it was widely condemned by Israeli political leaders, ${ }^{2}$ with Education Minister Naftali Bennett accusing Abbas of being a Holocaust denier (Pileggi, 2015). Less than one month later, on 20 October, Israeli Prime Minister Benjamin Netanyahu, addressing the $37^{\text {th }}$ Zionist Congress in Jerusalem, blamed the Holocaust on the Grand Mufti of Jerusalem, Haj Amin al-Husseini, who was a Palestinian leader during the Second World War. Netanyahu claimed that during a meeting in November 1941, al-Husseini persuaded Hitler to burn Jews rather than expel them from Germany (Prime Minister of Israel's Office, 2015). His comments provoked widespread criticism, and motivated German Chancellor Angela Merkel to state: "We know that responsibility for this crime against humanity is German and very much our own" (Chandler, 21

\footnotetext{
${ }^{1}$ Mandy Turner is the Director of the Kenyon Institute in East Jerusalem. Her research and publications focus on the politics of international intervention and the political economy of development in war-torn societies with a country focus on the occupied Palestinian territory, but also comparatively. She is the editor of From the River to the Sea: Palestine and Israel in the Shadow of 'Peace' (Rowman and Littlefield, 2019); and co-editor of The Politics of International Intervention: The Tyranny of Peace (with Florian P. Kühn; Routledge, 2016), Decolonizing Palestinian Political Economy: De-development and Beyond (with Omar Shweiki, PalgraveMacmillan, 2014), and Whose Peace? Critical Perspectives on the Political Economy of Peacebuilding (with Michael Pugh and Neil Cooper, PalgraveMacmillan, 2008). She lives and works in East Jerusalem.

${ }^{2}$ Apart from, of course, the political leaders of the Palestinian-Arab community in Israel.
} 
October 2015). It also led to a war of words with Palestinian political leaders; Saeb Erekat, former chief negotiator in the peace talks, stated: "Netanyahu hates Palestinians so much that he is willing to absolve Hitler for the murder of 6 million Jews" (Raved, 21 October 2015).

These two examples offer a succinct illustration of the focus of this article: the politics of comparison in the Israel-Palestine conflict as encapsulated through the use of these two analogies. The first is the 'Holocaust-Hitler analogy' used by Israel and its supporters, which portrays Israel as a beleaguered nation surrounded by anti-Semitic, Nazi sympathisers who seek to destroy it as the Jewish homeland. The second is the 'apartheid analogy', which compares the conflict to that of Apartheid-era South Africa, and portrays Palestinians as being the victims of racism and settler colonialism. The focus of this article is why, how and with what desired impact these two comparisons are frequently invoked. This investigation into the pursuit of political aims through comparing your rival or enemy to evil regimes and monstrous acts is divided into five sections. The first section briefly introduces the use of comparisons in foreign policy decision-making in conflict contexts, then outlines the focus and methodology of critical realism which is the intellectual framework used in this study. The rest of the article applies this framework and methodology to explore how, why, who by, and with what purpose, the Holocaust-Hitler analogy and the apartheid analogy have been used in the context of the Israel-Palestine conflict. The second section, which focuses on the use of the Holocaust-Hitler analogy, unpacks its dual role: first in the development of national cohesion in Israel against an "evil enemy", and second to build support internationally and to silence critics. The third section, which focuses on the use of the apartheid analogy, explores its dual role: first for Palestinians trying to make sense of the social reality they live under; and second to mobilise international support for their emancipation. The chapter concludes with a comparison of these two analogies by returning to the five series of enquiries developed in section one below, i.e. who is invoking each analogy and why, what are the social impacts of their use, to what extent the analogies capture reality, and whether the aim of these analogies is to advance domination or emancipation.

\section{'We're facing another Vietnam!' The case for analysing 'truth-claims' in conflict comparisons}

There is a body of research on the invocation of comparisons (through the use of analogies and metaphors) in politics, particularly in conflict contexts and especially as relates to foreign policy decisions to intervene in them. During many of the big conflicts of the $20^{\text {th }}$ and $21^{\text {st }}$ centuries, historical comparisons were used by policymakers and opinion-formers (such as journalists) who were sometimes just trying to make sense of events and sometimes using them as an explicit strategy to provoke support and action. While it is difficult to draw a direct link between the use of a comparison and a political decision, some researchers have sought to do so. One of the most comprehensive analyses in this regard is Analogies at War: Korea, Munich, Dien Bien Phu, and the Vietnam Decisions of 1965 (1992) by Yuen Foong Khong, which looked at the multiple comparisons utilised by US presidents, and how these influenced and guided certain foreign policy decisions. Vietnam, of course, itself went on to become an often-used 
analogy invoked by US policymakers and opinion-formers, particularly for instance in debates over US policy in Afghanistan (Apple, 2001; Miller, 2016).

In the post-Cold War world, a recurring comparison in US foreign policy discussions is the Holocaust-Hitler analogy. It has been invoked in two main ways: first, that a stance of non-intervention is effectively abandonment and could lead to genocide; and second, to demonise an opponent or 'enemy'. Secretary of State Madeleine Albright and President Bill Clinton, for instance, used it to rally support for military intervention in Kosovo in 1999 (Akrivoulis, 2015, p. 234); while President George W. Bush and Secretary of Defense Donald Rumsfeld invoked it in 2003 to justify regimechange intervention to overthrow the Iraqi Ba'athist regime (Dodge, 2016, p. 197-217; Desch, 2006, p. 119). In both contexts, as Akrivoulis (2015, p. 237-8) argues, the analogy served three important functions - integration (to rally domestic and international support), legitimation (justify intervention through a powerful moral discourse), and distortion (demonise one side in order to rule out certain policy options, i.e. there could be no negotiated settlement with "the enemy").

Problematically, however, political scientists often use the terms 'metaphor' and 'analogy' interchangeably. Although both are rhetorical devices in the realm of semiosis (i.e. the making of meaning), there are important differences between the two. The classical understanding of metaphor is that it is a word or concept borrowed from one context and utilised in a different context so that we understand something in terms of a "transferred meaning" (Maasen and Weingart, 2000, p. 19-20). For example, that a person is "as fit as a fiddle", or that "life is a rollercoaster". A man is obviously not a musical instrument (and how can a fiddle be "fit"?) nor is life a fairground attraction, but the use of such metaphors allow us to "see things" in a certain way. The use of metaphors also requires shared understandings that are socially, culturally and historically specific, i.e. for them to work, the audience requires prior knowledge and understanding of the metaphor. In the cases referred to above, people would need to know what a 'fiddle' is (and also that this is colloquial for a violin) and that the rollercoaster is a fairground attraction that goes up and down (causing both fear and joy) in order for the comparisons to work.

The two examples given above are benign and harmless, but there are also "transferred meanings" that are malevolent and harmful. For instance, when politicians or commentators use certain metaphors to build a repertoire of immigrants or refugees as "unwanted invaders" the implication is that they do not belong in the societies in question and should be driven out or prevented from entering (Parker, 2015; Shariatmadari, 2015). Metaphors can therefore be effective rhetorical devices employed to create a particular understanding of social reality, and can become a guiding force for future actions (Lakoff and Johnson, 1980, p. 75). But metaphors remain suggestive and hypothetical until they are confirmed or corroborated, and so their truth-claims cannot be taken for granted. An analogy, on the other hand, is a logical argument that seeks to demonstrate shared characteristics, and thus it normally contains a "sense of essence" (Hofstadter, 1995, p. 75).

Let us remain with the refugee example for an illustration of the difference between metaphor and analogy. In 2015, UK media commentator Katy Hopkins referred to refugees fleeing war and famine as "cockroaches". Obviously, they are not literally cockroaches, but what Hopkins did was employ the metaphor of an insect popularly 
understood as a dirty pest in order to "transfer meaning" so that the reader would be suitably disgusted and conclude that refugees should be excluded or exterminated. In response, UN High Commissioner for Refugees Zeid Ra'ad Al Hussein then employed an analogy to criticise Hopkins' comments by accusing her of using language akin to that of Nazis and Hutu genocidaires (Stone, 24 April 2015). While Hopkins is neither a Nazi nor a Hutu genocidaire, her language is certainly reminiscent of them, and so there is a "sense of essence" to Al Hussein's comparison that cannot be said for Hopkins'.

The debate about whether, and to what extent, there is a "sense of essence" in any concept and how it relates to social reality is one that deeply divides social and political theorists. Post-structuralists reject the idea of a "sense of essence" and idealise the "intersubjective production of meaning" that "conflates discourses and material practice" (Fairclough et al, 2002, p.2). For post-structuralists, therefore, one analogy or metaphor would have just as much legitimacy as another because there would be no ability to assess whether and to what extent it makes truth-claims and captures reality; in fact, they would reject the pursuit of such an analysis. They would only focus on understanding the way in which the analogy or metaphor was used and for what purpose, and the intentions of those employing it. While these aspects form an important part of the analysis in this article, by rejecting the possibility of assessing truth-claims and 'essence', a poststructuralist perspective restricts the analysis of conflict comparisons in ways that hampers understanding.

Critical realists, on the other hand, insist there are not only 'signifiers' (e.g. words) and 'signified' (concepts) but there are also 'referents' (the material world). Critical realism operates with an ontology that distinguishes between the 'real' (objects, their structures, and their causal powers), the actual (what happens when these powers are activated and produce change), and the empirical (a subset of the 'real' and the 'actual' that is experienced by actors). So while the 'making of meaning' is a central aspect of social reality, it does not constitute it. The 'making of meaning' is "both socially-structuring and socially-structured", which means that the stories we create to understand various situations structure and "make" meaning, but that these "meanings" are constructed and only make sense because of a shared history, culture, and social relations (Fairclough, 2003, p. 16-30). These will, of course, vary from case to case, thus allowing a range of interpretations. Akin to post-structuralists, critical realists are interested in how these meanings are constructed and the motives of those who employ them. However, in addition and in distinction, they are also interested in the truth-claims and appropriateness of these "meanings" (Fairclough et al, 2002, p. 5).

Because metaphors and analogies are "effective elements in the interplay of power/knowledge" (Maasen and Weingart, 2000, p. 21), we should not just analyse how they emerge and become dominant, but also how societal power relations are either reinforced or challenged by their use, and whether domination or emancipation is the desired object and outcome of their application. For example, referring to refugees as 'parasites' is designed to provoke disgust and violence against a powerless sector of society, while leaving uncriticised and intact what created them in the first place.

This article therefore employs a critical realist perspective in its analysis of the use of metaphors and analogies in conflict comparisons. It adapts aspects of Fairclough's critical discourse analysis (CDA) and utilises insights from Fairclough, Jessop and Sayer's quest to integrate semiosis with critical realism. Fairclough's (1995) 
CDA framework maps three separate forms (and levels) of analysis on to one another: i) at the micro level - of spoken or written language texts (e.g. through the use of metaphor and rhetorical devices); ii) at the meso level - of processes of text production, distribution and consumption (i.e. who is producing it and who is consuming it); and iii) at the macro level - of instances of sociocultural practice (i.e. the broader environment in which the discourse is being received and perceived, accepted or rejected, acted on or not). Also important to this framework is Fairclough, Jessop and Sayer's insistence on identifying and exploring the "extra-semiotic conditions" that make semiosis possible and potentially effective, i.e. the influence of the 'habitus' (abstract mental habits and schemes of perception) which is culturally produced; as well as the "truthfulness" and appropriateness of certain analogies and comparisons, i.e. their relationship with the material and social world (Fairclough et al, 2002, p. 5-8). This analysis therefore adopts a verificationist perspective, i.e. that metaphors and analogies should be empirically testable. However, it also recognises that even if the comparison employed does not bear much resemblance to reality, it still has political significance because it creates a framework of understanding and potentially a call to action.

The proceeding analysis of the use of analogies in conflict comparison in the case of Israel-Palestine is guided by five series of enquiries developed from these insights: first, on the way in which the analogy has been invoked and by whom; second, on the intentions of those employing it; third, on the social causes and effects of its use; fourth, on whether and to what extent it captures reality or an 'essence' of the situation to which it is being compared; and fifth, whether the intentions of its invocation are to dominate or to emancipate. The main source of data is literature on the use of these analogies, news articles, speeches, plus visits to Yad Vashem in Jerusalem and Mandela Square in Ramallah. The following section uses these five series of enquiries to explore the use of the Holocaust-Hitler analogy as applied to Palestinians.

\section{The Holocaust-Hitler analogy and the politics of 'never again'}

The Holocaust was the state-sponsored persecution and murder of around six million Jews (as well as other groups such as the Roma, communists, and gay and disabled people) by the German Nazi regime and its collaborators in Europe. It devastated and nearly wiped out European Jewry through mass extermination in gas chambers, after forced displacement into ghettoes, transit camps, and labour camps. The Nuremberg Trials, held between November 1945 and October 1946, prosecuted prominent leaders of the Nazi regime, advanced international law as pertains to war crimes, and were the first forums for the prosecution of crimes against humanity, including the crime of genocide. The Holocaust provoked the creation of the UN Genocide Convention in 1948, which most countries have incorporated into their domestic laws, and which was transferred into the Rome Statute of the International Criminal Court.

It is clear that the Holocaust has had a decisive impact on the identity, ideology and politics of Israel (Segev, 2000). Barely a day goes by where there is not a reference to it by Israeli politicians and other opinion-formers such as journalists; and it is often invoked against those regarded as enemies of the Israeli state. As such, only a small selection of examples of its use are utilized here in order to shed light on the five series 
of enquiries as outlined in section two above; furthermore the focus is on its use against Palestinians.

A visit to Yad Vashem, the Holocaust museum at Mount Herzl on the outskirts of Jerusalem, is an appropriate place to start. "From Holocaust to Rebirth" is the powerful narrative woven while visitors are led through 10 exhibition halls, ending with the miniature reconstruction of a Nazi gas chamber and photos of the emaciated bodies of those liberated from the camps, next to pictures of David Ben Gurion (first Prime Minister of Israel) making Israel's Declaration of Independence speech on 14 May 1948. Upon exiting the museum, the "Connecting Path" leads you from Yad Vashem to Har Herzl, which hosts the Mount of Remembrance, i.e. the graves of soldiers killed in combat, victims of terrorist attacks, and Zionist leaders. Along this route are information displays relaying the history of Jewish persecution (most prominently the Holocaust), the emergence and history of Zionism, the Zionist struggle in the final days of the British Mandate, and the birth of the State of Israel - thus linking all of these events in one continuous historical narrative.

The main take-home narrative from Yad Vashem is that the establishment of the State of Israel liberated Jews from millennia of discrimination and genocide. Soldiers in the Israel Defense Forces are given tours by soldier-guides who present a strong narrative that Israel and the Israeli army plays a central role in protecting Jewish lives (Israel Defense Forces, 29 April 2014). Soldiers also visit Holocaust survivors and Holocaust sites (Efraim, 2014; Israel Defense Forces, no date). Holocaust education in Israel plays a central role in tying the survival of the Jewish people to the existence of the state of Israel, and in constructing the fear of an existential threat for Jews (GurZe'ev, 2000, p. 378). This is passed on through the education system, popular culture and the media. For instance, every year since 1988, 10,000 Israeli high school students, accompanied by Holocaust survivors, visit Yad Vashem and Holocaust sites (Klar, et al, 2013, p. 128). The Holocaust has therefore played a crucial role in the formation of an Israeli national narrative and sense of loyalty to the state. But, according to critics, this collective historical memory has also fuelled a trauma of victimhood and a type of "siege mentality" (Magal et al, 2016, p. 1224).

In addition to its role in the Israeli national consciousness, the Holocaust has also been invoked as an analogy to demonise opponents and 'enemies'. Comparing Palestinians to one of the most evil regimes of the modern period which explicitly set out to exterminate Jews in Europe has become an important part of Israel's politics of nationhood: it was a powerful mobilizing tool to help promote and justify the violence against Palestinians that made the birth of the state of Israel possible, and it created an ever-present existential threat thus providing a rationale for the continued use of violence to the present day. Zertal (2005, p. 4) argues that: "There has not been a war in Israel, from 1948 till the present ongoing outburst of violence which began in October 2000 [the book was published in 2005], that has not been perceived, defined, and conceptualized in terms of the Holocaust." Comparing Palestinians to Hitler is a powerful tool because, as Normand (2016, p. 4) argues, "he has become the ultimate symbol of evil." And so Netanyahu's accusation, referred to in the introduction to this article, about al-Husseini being one of the driving forces behind the 'Final Solution', was merely a reiteration of similar accusations made by all previous Israeli leaders right back to Ben Gurion to describe Palestinian leaders and wider Palestinian society. In August 
1947, for example, Ben Gurion equated Arabs (including Palestinians) with Nazis and warned that they "know only one way of solving the Jewish problem: total destruction" (Zertal, 2005, p. 173). Menachem Begin, Prime Minister from 1977 to 1983, made prominent use of Holocaust imagery in his speeches, warning time again about the "return of Auschwitz" in reference to threats from Palestinians and Arab nations (Alexander and Dromi, 2011, p. 19). In fact, all Palestinian leaders and many Arab leaders from different eras have been compared to Hitler and/or been accused of being Nazis (Normand, 2016, p. 114). In the run up to the 1967 Arab-Israeli War, Israeli soldiers and politicians frequently claimed that Israel was facing a Holocaust-like disaster. In the context of the bombastic speeches of Egyptian President Gamal Abdul Nasser, this helped to promote worldwide support for Israel which, in this circumstance, was regarded to be battling for its existence against the combined strength of its Arab neighbours.

United States' support for Israel was cemented after its success in the 1967 War and grew because of Israel's role as a strategic regional ally (Pappe, 2007). From then on, awareness of the Holocaust grew in mainstream American culture to eventually take the dominant position it holds today (Novick, 1999). The Holocaust has become an important part of American discourse and politics, including foreign policy decisions, particularly on Israel and Palestine (Finkelstein, 2000). In 1994, for instance, former President Richard Nixon wrote: "No American president will let Israel go down the tubes [because] Israel is a haven for millions whose families endured incredible suffering during the Holocaust" (Desch, 2006, p. 108). The Holocaust has thus become a central narrative practice which embeds the idea that the survival of Israel is essential for the survival of the Jewish people, particularly in the collective mind-set of its most powerful ally, the United States. Englert (2018) also charges that this narrative practice allows Western states to sidestep their history of endemic anti-Semitism by giving them a 'quick-fix' through supporting Israel.

When Israel expanded its control over the whole of Mandate Palestine after the 1967 War by occupying the West Bank and Gaza, the comparison was still employed. In 1969, Israel's foreign minister Abba Eban compared a return to the pre-1967 'borders' (the 'Green Line') of Israel with a return to the borders of Auschwitz (Alexander and Dromi, 2011, p. 20). Holding on to the OPT has been repeatedly portrayed as being essential for Israel's survival by most Israeli politicians (and the settler movement). This reference to the 1967 'borders' being "Auschwitz borders" has been asserted on a number of occasions despite the fact that it makes no sense given that Auschwitz had no 'borders' as such. But the imagery created is a powerful one that somehow manages to equate but switch two completely opposite roles, i.e. the colonizer and occupier is transformed into the persecuted victim. For instance, 'One Family', the biggest fund for victims of terror attacks in Israel, had an advertisement on the English website of the Israeli newspaper, Ha'aretz, that juxtaposed images of Passover, the Holocaust, and the Second Intifada, which stated: "In every generation, they rise against us, to annihilate us" (Ochs, 2006, p. 360). And to coincide with the International Court of Justice ruling on Israel's Separation Barrier in February 2004, the Israeli Foreign Ministry coordinated a protest outside the court of Israelis who had experienced terror attacks; when a reporter for Israeli Channel 1 asked the widow of a victim for a 
message, she replied: "I want to tell the entire world not to close your eyes. Don't ignore this in the same way as they ignored the Holocaust" (Ochs, 2006, p. 363).

The main effects of the use of the Holocaust has therefore been to create a sense of existential angst in the Jewish-Israeli population, and has turned the slogan "never again" into belief in, and support for, a specifically Jewish state with military strength to defeat its enemies. For example, displayed in the office of General Meir Dagan, head of the Mossad from 2002 to 2008, was a photograph of an old Jewish man next to a trench with a rifle aimed at his head by an SS officer. When asked about it, Dagan would reply: "This old Jew was my grandfather. We should be strong, use our brain, and defend ourselves so that the Holocaust will never be repeated" (Klar et al, 2013, p. 135). When this is coupled with the portrayal of Palestinians as akin to the Nazis, an act of collective cognitive dissonance is being employed whereby the heinous act of genocide against 6 million Jews that took place in Europe is transferred to the Arab world in a curious case of the militarisation and geographical displacement of a tragedy. Indeed, Loshitzky (2006, p. 328) argues that: "The Arab, and particularly the Palestinian, was to become the container of Jewish fantasies of power and revenge."

Equating Palestinian resistance - both violent and non-violent strategies - with Jewish annihilation is a powerful mobilizing narrative, for both Jewish-Israelis and Jews worldwide. During the Second Intifada, for instance, an Israeli army officer told foreign journalists he was happy to invade Palestinian towns and cities in the West Bank because he was making sure that what happened to his mother, who had been an inmate at Bergen-Belsen concentration camp, would never happen again (Loshitzky, 2006, p. 332-3). And in the documentary film 'Israel's Volunteer Soldiers' a Belgian volunteer reveals he was motivated to serve in the Israeli military because he was a grandchild of Holocaust survivors and that "this was my revenge" (Aljazeera, 2017).

There are multiple other examples that could be used here but these suffice for the purposes of this article. It is important for the remainder of this section to assess the extent to which the Holocaust-Hitler analogy captures reality or an 'essence' of the situation to which it is being compared, i.e. whether Palestinians are Nazis and whether Israel is at risk of genocide and annihilation from them.

This article does not seek to assert there were (or are) no Nazi sympathisers or Holocaust deniers in the Middle East, as there clearly were (e.g. al-Husseini) and is (e.g. former Iranian President Mahmoud Ahmadinejad). It is also clear that Nazi symbols (e.g. the swastika) are occasionally used by Palestinian protestors, although less often than you would think, and this is individualised and random, i.e. it is not part of any faction's political platform. The reasons for this are complex: sometimes they are used to identify Israel with the Nazis, sometimes they are used provocatively because it is known that such symbolism is hated by Israelis. ${ }^{3}$ But the constant references to Yasser Arafat, Chairman of the PLO, being akin to Hitler do not accord with reality, because it is difficult to substantiate the accusation that he was anti-Semitic. In addition to al-Husseini, the strongest case can be made against current PA President, Mahmoud Abbas, whose 1982 doctoral dissertation made remarks denying the Holocaust (Achcar, 2010, p. 270). But he subsequently acknowledged the tragedy of the Holocaust, stating:

${ }^{3}$ I am grateful to Toufic Haddad for this point. 
"When I wrote 'The Other Side' [his thesis] we were at war with Israel. Today I would not have made such remarks" (Myre, 11 March 2003).

The reasons for, and extent of, Holocaust denial in the Arab world have been explored by Litvak and Webman (2009), and Achcar (2010). Litvak and Webman (2009, p. 379) argue that it intensifies during moments of anxiety when Israel's strength is unopposed, whereas eras of diplomacy have brought greater recognition of Jewish experience of persecution and suffering. Achcar criticises the idea that Palestinians bear some responsibility for the Holocaust because they demanded that Britain restrict Jewish migration to Mandate Palestine. He regards this accusation to be hypocritical because other countries, including the United States, also restricted Jewish immigration. Furthermore, he argues that Palestinians should not be blamed for resisting a project whose avowed goal was to establish a foreign state on their land. Achcar (in Berlin, 2010) condemns the use and abuse of the Holocaust-Hitler analogy by Israelis and Arabs alike, but insists that the comparisons drawn between Israel and the Nazis by Arabs are a reaction to decades of Israeli comparisons of Arab leaders with Hitler.

It is difficult not to conclude, therefore, that the main intention behind the use of the Holocaust-Hitler analogy is to create and demonise an 'enemy', to portray yourself as morally superior, and (for some) to justify the use of violence (Normand, 2016, p. 114). It is impossible to analyse the international impact of the comparison, but it is clear that most world leaders are sceptical of its use against Palestinians. Nevertheless, its repeated invocation supports the narrative that Israel is the only thing protecting Jews from another Holocaust and it serves to foster guilt amongst Western states at their policies during the Nazi era as well as during and directly after the Second World War, all of which fuels the belief that Israel should be given unequivocal support. As Massad (2006, p. 129) argues: "Zionism and Israel asserted that any acknowledgment of the holocaust is an acknowledgment of Israel's 'right to exist,' and conversely that any attempt to deny Israel its alleged right to exist was perforce a denial of the holocaust." This has helped facilitate the criminalization in the United States and large parts of Europe of criticisms of Israel's oppression of Palestinians. Opposition to the occupation and campaigns for the decolonization of Israel are now presented as constituting a new form of anti-Semitism (Gordon, 2018).

But is Israel really at risk of annihilation from Palestinians? Not in the objective sense in that a comparison of military capabilities and casualties leaves no doubt as to who has the upper hand. The Palestinian national movement was a guerrilla organization which was defeated and ejected from Jordan and Lebanon, and which has morphed into a rag-bag of political factions (armed, if at all, with primitive weapons) and Palestinian Authority security forces under the direct control of the US Security Coordinator and tied into security relationships with Israel. Neither PA security forces nor the Palestinian political factions have been able to stop or reverse Israel's colonization of Palestinian land or Israel's oppression of their people. Comparing these actors to Nazis thus strains credulity, but the "transferred meaning" for Jewish-Israelis when this comparison is made is that they face an existential threat of annihilation. The international message which is transmitted is that Israel faces evil enemies who need to be controlled and/or defeated, and that it should not be criticised for doing so.

In one sense, however, Palestinians are a threat against Israel if we remember that Zionism is a movement and state ideology that insists on enshrined legal-political 
privileges for Jews and regards Jews to be the only people entitled to national rights in the area that used to be Mandate Palestine. However, this is not the same as being a threat to the Jewish people or even to the presence of Jewish-Israelis in a future Palestinian state. In fact, it says more about the Israeli vision of nationhood and its own practices that the two are considered equivalent. ${ }^{4}$

Under current conditions, Israel controls the whole space between the Mediterranean Sea and the Jordan River, but Palestinians in the OPT are living under a separate legal and political regime with no right to vote in Israeli elections and no access to the rule of law. On the other side of the 'Green Line', Palestinians in Israel (who make up 20 per cent of the Israeli population) who lived under military rule until 1966, continue to face discriminatory practices, and are regarded as second class citizens as codified in the July 2018 Nation-State Law (Mendel, 2019). Furthermore, millions of Palestinian refugees have been left with no compensation or right of return because Israel refuses to allow it, arguing that their return would destroy Israel as a Jewish state as Jews would thereafter be a minority. While the post 9/11 zeitgeist in the United States and Europe has provided a fertile environment for Israel to portray its oppression of a people struggling for liberation and national self-determination as being part of the 'war on terror', critics charge that if Israel does not allow a sovereign Palestinian state to emerge then what will exist is an apartheid regime in which Israel rules over millions of Palestinians who have no rights. The apartheid analogy, which has been invoked by Palestinians and their supporters, is thus explored in the following section.

\section{The Apartheid Analogy and Palestine's 'South Africa moment'}

Apartheid was a system of institutionalised racial segregation and discrimination in South Africa between 1948 and 1991 to ensure white minority dominance over the majority African population. While it only became official state policy in 1948, this system was built on centuries of European settlement and colonialism during which time black South Africans were dispossessed of their land, liberties and rights. It was marked by 'grand apartheid' and 'petty apartheid': grand apartheid restricted movement and residence, which later turned into territorial segregation (the Bantustan 'homelands'), as well as limiting employment opportunities; while petty apartheid restricted interaction between whites and non-whites by segregating public facilities and social events. It was a brutal regime based on discrimination, territorial fragmentation, and political repression. It sparked widespread international condemnation, with the General Assembly of the United Nations designating it a crime against humanity and passing the International Convention on the Suppression and Punishment of the Crime of Apartheid in 1976. In 1977, apartheid was classified as a grave breach of the Geneva Conventions when practiced in situations of armed conflict and as such is a war crime, and it was retained as a crime against humanity in the 1998 Rome Statute of the International Criminal Court (Dugard and Reynolds, 2013). The label is more commonly associated in the popular mindset with its experience in South Africa, however,

\footnotetext{
${ }^{4}$ I am grateful to Sai Englert for this point.
} 
'apartheid' is actually legally defined. While the analogy has been used in other contexts, it has been more frequently invoked to describe Israel's rule over Palestinians. There are differences in opinion as to its geographical applicability, i.e. whether it should only apply to the Palestinian territory occupied since 1967 (the OPT) which covers Gaza and the West Bank (sometimes including or excluding illegally annexed East Jerusalem), or whether it is applicable to the whole area that covered Mandate Palestine (i.e. Israel plus the OPT including annexed East Jerusalem).

Like the previous section on the Holocaust-Hitler analogy, this analysis of the apartheid analogy, invoked by Palestinians (and some international commentators) to compare their treatment by Israel with South Africa's treatment of non-whites during its apartheid era, focuses on the five sets of enquiries outlined in section two.

An appropriate place to start this analysis is Mandela Square in Ramallah where, in April 2016, a six-metre statue of Nelson Mandela was unveiled. At the inauguration ceremony, South African and Palestinian leaders drew parallels between their liberation movements. Ramallah, the seat of the Palestinian Authority (the non-sovereign governing entity established after the 1993 peace accords), is twinned with Johannesburg whose leaders donated the statue. The PLO and the African National Congress (ANC) have had a long-standing relationship as anti-colonial movements seeking liberation. In the early 1970s, the PLO and many Palestinian political factions compared Israel's proposals for Palestinian autonomy (expressed through the Allon Plan) to the Bantustan strategy of South Africa (Clarno, 2017, p. 3). And leading figures from the South African anti-apartheid movement have continuously drawn parallels between apartheid South Africa and Israel, particularly Nelson Mandela, Archbishop Desmond Tutu, Oliver Tambo, and Ronnie Kasrils. For instance, addressing the UN General Assembly in 1982, Tambo compared the Middle East and southern Africa in terms of the region-wide violence being perpetrated by Israel and South Africa, and the similarities in their liberation struggles (Kasrils, 2015, p. 32). In 1997, when apartheid in South Africa had long ended, Mandela said: "We know too well that our freedom is incomplete without the freedom of the Palestinians" (Prusher, 2013). And Tutu (2002, 2012) has repeatedly accused Israel of being an apartheid regime, provoking Alan Dershowitz (2010), US lawyer and prominent Israel supporter, to accuse him of antiSemitism and of minimising the Holocaust, which indicates how both analogies are frequently invoked as a retort to each other, as also exemplified by the quotations in the introduction to this article. The use of the analogy by prominent South African antiapartheid activists, however, gives it more credibility and moral weight. Even the architect of apartheid, Hendrik Verwoerd, South Africa's prime minister in the late 1960s, considered Israel to be a kindred spirit practicing an apartheid against Palestinians akin to their policies against black South Africans (McGreal, 2006a). Palestinian and South African leaders have three intentions by invoking the comparison: first, to provide an analysis of their common experiences of oppression; second, to create solidarity and link their anti-colonial struggles; and third, to advance support in international organisations to outlaw such racist modes of governance. In recognition of this, and signalling the activism of developing countries in international affairs in the 1970s, a number of international bodies passed resolutions that compared Zionism with apartheid. In 1975, for instance, the UN General Assembly passed Resolution 3379 which "determine(d) that Zionism is a form of racism and racial 
discrimination"; the Organization of African Unity passed Resolution 77 which linked the regimes of Israel, Rhodesia and South Africa to a common racist structure and imperial origin; and the Non-Aligned Movement condemned Zionism as a "threat to world peace" (Knopf-Newman, 2011, p. 41-43).

After 1988 there was less use of the analogy, particularly by the PLO leadership. This reflected changes taking place whereby the PLO gave up its goal of a secular, democratic state in the whole of historic Palestine, instead accepting a solution to the conflict in the creation of a specifically Palestinian state on only 22 per cent of the land. The PLO thereafter de facto accepted Israel as a Jewish state even if it has rejected attempts to make it endorse this de jure. This change in PLO policy was a precondition of the US-sponsored peace talks between the PLO and Israel. Another Israeli precondition for participating in these talks, was that UN General Assembly Resolution 3379 be rescinded - which happened in December 1991.

But the failure of the peace process, the breakdown of talks at Camp David in 2000 , and the growing realisation that Israel was blocking the emergence of a sovereign Palestinian state fuelled the re-emergence of use of the apartheid comparison, mostly from civil society activists within and outside the OPT as well as some of the Palestinian political factions, although not initially from the Palestinian Authority and PLO leadership. The failure to implement the two-state solution; the huge increase in numbers of Jewish-Israeli settlers in the OPT (who live under Israeli civil law while Palestinians live under military law); and Israel's closure regime of checkpoints, roadblocks and the Separation Wall (referred to by some as the "Apartheid Wall") has given the comparison renewed vigour and relevance. Indeed, in 2004, Ronnie Kasrils said after visiting the OPT: "This is much worse than apartheid. The Israeli measures, the brutality, make apartheid look like a picnic. We never had jets attacking our townships. We never had sieges that lasted month after month. We never had tanks destroying houses. We had armoured vehicles and police using small arms to shoot people but not on this scale" (in McGreal, 2006b).

In 2001, an attempt was made to resurrect the charge that Zionism is a form of apartheid and colonialism at the World Conference on Racism, which took place in Durban, South Africa. This conference (which was authorised by the UN General Assembly) ended in controversy and is a stark example of the huge divide that exists between Western states and states that experienced Western violence through slavery and colonialism. Efforts to discuss Israel's multiple violations of Palestinian rights were stymied by the withdrawal of the United States and Israel from the conference; many European states also rejected the accusation that Zionism is a form of apartheid.

The year 2005 marks a major turning point in the use of the comparison: the Palestinian Boycott, Divestment and Sanctions (BDS) movement was created; and the first Israeli Apartheid Week was established. The BDS movement was launched when 171 civil society groups in the OPT issued a call for boycott, divestment and sanctions against Israel. Drawing inspiration from the anti-apartheid struggle in South Africa and the US civil rights movement, BDS discerned three minimum requirements for a just peace: an end to Israel's military occupation of Gaza and the West Bank (including East Jerusalem) as well as Arab lands in Syria and Lebanon; an end to racial discrimination against Palestinian citizens of Israel; and the right of return for Palestinian refugees as enshrined in UN General Assembly Resolution 194 (Barghouti, 2011, p. 49). The BDS 
movement draws on international law, particularly the 1973 International Convention on the Suppression and Punishment of the Crime of Apartheid and the 2002 Rome Statute. Omar Barghouti (2011, p. 63), one of the movement's leading campaigners, has explicitly called BDS the "South Africa strategy for Palestine." Also in 2005, the first Israeli Apartheid Week was held in Toronto, Canada, with a programme of events, speakers and protests that focused on Israel's policies towards Palestinians.

By 2019, IAW featured more than 200 events, across 30 countries, on five continents (Israel Apartheid Week website, no date). Using a variety of techniques including installations that resemble the Wall and checkpoints, mock eviction notices, plus lectures and film showings, IAW has been controversial, provoking clashes on university campuses between supporters and critics.

In both cases, the goal of the use of the term 'apartheid' and the comparison with South Africa has been to highlight Israel's practices against Palestinians and mobilise internationally amongst consumers, workers, students, and transnational activist networks. And it is in the realm of civil society that the term 'apartheid' has been invoked most frequently by groups such as B'Tselem, Jewish Voice for Peace, Code Pink, Artists Against Apartheid, and the BDS movement, to name but a few. The stated aims of these groups is to build global support for Palestinian rights and a credible case for a legal challenge against Israel in the International Criminal Court for the crime of apartheid. The role of the apartheid analogy is thus to help institute a "paradigm shift in the international community's approach to the conflict" (Jacobs and Soske, 2015, p. 2). The social effects of the analogy are therefore to be found not so much in the OPT and Israel (although Israel has passed legislation outlawing BDS and is preventing supporters from entering Israel), but more specifically internationally where the battle for public opinion has become increasingly acrimonious.

Just as with the Holocaust-Hitler analogy, journalists have also invoked the apartheid analogy but largely to explore the validity of the comparison. For instance, in 2006, The Guardian (London) ran an extensive two-part report written by Chris McGreal (2006a, 2006b) that analysed the charges made by Palestinians and their supporters. McGreal has reported from both Johannesburg and Jerusalem, so was regarded as well placed to make comparisons. McGreal does not offer any firm conclusion as to the legitimacy of the comparison, but there is little doubt that he considers it valid in some ways - through his analysis of Israel's various forms of institutional, legislative and societal discrimination; the unequal education system; land confiscation and unequal access to land; discriminatory planning and urban policy; the differential treatment of Israeli settlers and Palestinians in the OPT; the Wall and policies of separation; the high levels of military violence used by Israel; and Israel's close relationship with apartheid South Africa which continued while the rest of the world was moving towards shunning it. McGreal was criticised for this report, including a complaint to the UK Press Complaints Commission (which was dismissed) by the pro-Israel lobby group Camera, the Committee for Accuracy in Middle East Reporting in America. There are many other journalists who use the analogy (e.g. Peter Beinart and Ben White), or reject it (e.g. Melanie Philips and Benjamin Pogrund).

Academics have also invoked the analogy. Early examples include Maxime Rodinson in 1973, and Uri Davis in 1987. But paralleling the recent increase in its use by activist groups, more academic studies have emerged. In 2009, for instance, the 
Human Sciences Research Council of South Africa (2009), the country's statutory research agency, released a 300-page report concluding that Israel was practicing colonialism and apartheid.

International lawyers have also been more active in the past decade with notable examples coming from two former UN Special Rapporteurs for Human Rights in the Palestinian Territories Occupied Since 1967: John Dugard (2004-07) and Richard Falk (2008-14). In his 2007 report, Dugard, a South African professor of international law, concluded that some of Israel's practices in the OPT were "reminiscent" of apartheid South Africa. In a 2016 interview, Dugard explained that he would have used the apartheid label earlier but refrained because he wanted to avoid censure from Western states (Johnston, 2007). Falk, professor emeritus of international law at Princeton University, also argued that Israel's regime over the Palestinians "exhibits features of colonialism and apartheid" (2010, p. 2). Detained at Ben Gurion airport and deported on his first visit to Israel as Special Rapporteur in 2008, Falk faced extensive criticism from Israel and its supporters, including charges of anti-Semitism, despite the fact that Falk is Jewish (Turner, 2019).

The apartheid analogy has also been invoked by some unexpected people, for instance by former US President Jimmy Carter in 2006, and by US Secretary of State John Kerry in 2014.

Those who use the apartheid analogy are often accused of being anti-Semitic and of delegitimising Israel (Shimoni, 2007). However, this accusation is somewhat blurred by the fact that many Jewish-Israeli politicians and former politicians have also used the analogy. Former Prime Minister Ehud Olmert has raised it repeatedly as a clarion call in favour of ending the occupation and for a two-state solution (McCarthy, 2007). Former Prime Minister Ehud Barak has warned of Israel being on a "slippery slope" towards apartheid (Sommer, 2017). And in 2013, Justice Minister Tzipi Livni used the term to argue for the resurrection of peace talks (Times of Israel, 18 January 2015). The apartheid analogy, in these circumstances, is being used as a warning against the Israeli government, which is working towards annexing large parts of the West Bank - a move that would, in the eyes of critics, ensure perpetual conflict with Palestinians.

As with the Holocaust-Hitler analogy, multiple other examples could be documented here, but these suffice to illustrate who invokes it, for what purpose, and with what intention. It is important now to assess the truth-claims of the apartheid analogy - does it represent an "essence" of the reality to which it is being compared, i.e. is Israel practicing apartheid against Palestinians?

One of the problems with the analogy is that some who invoke it - on both sides of the debate - get caught up in comparing it with the South African experience rather than understanding it as defined under international law. Article 9 of the Rome Statute states: "The 'crime of apartheid' means inhumane acts of a character similar to those referred to in paragraph 1, committed in the context of an institutionalised regime of systematic oppression and domination by one racial group over any other racial group or groups and committed with the intention of maintaining that regime" (UN, 2002). While Israel is not party to two of the key treaties (i.e. the Apartheid Convention and the Rome Statute), the designation 'apartheid' has clear implications under public international law for Israel as well as third parties in terms of the duties of cooperation, non-cooperation and assistance. The significance of the apartheid analogy therefore 
lies in its designation as an international crime and thus its legal prohibition; indeed, apartheid is illegal under the rules of public international law, whereas occupation is not (Dugard and Reynolds, 2013, p. 912-913). The term carries a lot of legal and political purchase, which means that when it is used, particularly in international bodies such as the UN, Israel and its supporters have strongly opposed it thus turning the UN into one of the major diplomatic battle-sites for the Israel-Palestine conflict. Indeed, many more UN bodies and employees beyond the UN Human Rights Council (which hosts the UN Special Rapporteur system) have argued that Israel's repression of Palestinian selfdetermination and human rights exhibits aspects of apartheid. In 2008, for instance, President of the UN General Assembly Father Miguel D-Escoto Brockman urged that the UN use the term apartheid to describe Israel's policies towards Palestinians. And in March 2012, the UN Committee on the Elimination of Racial Discrimination censured Israel under the rubric of apartheid and segregation as prohibited by Article 3 of the Convention (Dugard and Reynolds, 2013, p. 869-70; p. 912). However, like South Africa before it, Israel and its supporters (particularly the United States) regards the UN to be biased against it - and so it frequently criticises the international body and has withdrawn its membership from some UN agencies.

While there will continue to be disputes as regards the extent to which the apartheid analogy captures reality or an "essence" of the situation to which it is being applied, it is clear that the intentions of those invoking it is to advance Palestinian rights and self-determination - whether that be as a sovereign state existing side-by-side with Israel or whether that be in one democratic state with equal rights for all citizens.

\section{Conclusion: Monstrous metaphors or analogies with 'essence'?}

Comparisons made through the use of analogies and metaphors are essential parts of our everyday speech, history, and politics by providing explanations and 'shortcuts' for understanding things through the "transfer of meaning". It is therefore hardly surprising they are frequently used in conflict contexts, such as in Israel and Palestine. What is crucial to note, however, particularly in this case, is just how closely tied are the two comparisons analysed in this article. The Jewish-American academic Marjorie N. Feld (2013) once said: "My own work on American Jews and apartheid suggests just how intense and difficult it is to talk about Israel and apartheid, with the Holocaust and its legacy playing a role in nearly every conversation." While it is difficult to talk about these comparisons as their use provokes anger from both sides, they are the two main rhetorical frameworks through which both sides see their respective victimhood, and this alone demands we assess them. This conclusion therefore returns to the five series of enquiries used to guide this analysis: first, on the way in which the analogy has been invoked and by whom; second, on the intentions of those employing it; third, on the social causes and effects of its use; fourth, on whether and to what extent it captures reality or an 'essence' of the situation to which it is being compared; and fifth, whether the intentions of its invocation are to dominate or to emancipate.

By using comparisons associated with two monstrous regimes - Nazi Germany and apartheid South Africa - there is little doubt that the desire is to establish and demonise an enemy and build support by using comparisons that many will understand, be suitably disgusted by, and mobilise to fight against. For both comparisons, it is 
political elites, opinion formers, and civil society activists who use them. In the case of the Holocaust-Hitler comparison, however, this also enjoys sponsorship from the Israeli state. The apartheid comparison, on the other hand, has been mostly driven by civil society actors, initially by leaders of the Palestinian resistance and other national liberation movements, and more recently by civil society organisations and opinionformers (Palestinian, Israeli, and international); it is only lately that Palestinian political elites have again used it publicly, such as exemplified by Abbas's speech to the UN quoted in the introduction to this article.

The social causes and effects of the use of both comparisons, and their relative 'truth-claims' are a bit more difficult to assess. There is no doubt that Israel and its supporters regard the Holocaust-Hitler comparison as justified and necessary because of the prevalence of anti-Semitism and the fact that Israel resides in a region hostile to its existence. But, as explored in the third section, the Holocaust took place in Europe, not the Middle East. It emerged from centuries of discrimination and persecution of Jewish communities, and it was a specifically European phenomenon. This is not to deny that anti-Semitism exists in other parts of the world, because it obviously does. However, Palestinians in the OPT are not in a position to threaten the Israeli state militarily in any meaningful way, despite claims to the contrary. Further, the intent and goal of Palestinian nationalism is neither to eliminate the Jewish people (this is a conflict with Israel not with Jews), nor to install a fascist regime (this is a national liberation movement). ${ }^{5}$

The threat, as identified by Israel itself, comes from a potential change in international public and elite opinion which could lead to pressure for it to withdraw from the OPT and to allow a sovereign Palestinian state to emerge. The current political leadership in Israel has ruled this out and its strategy has been to continue colonising Palestinian land, which will require the perpetuation of the military occupation and suppression of Palestinian resistance to dispossession and oppression. It is difficult not to conclude, therefore, that the Holocaust-Hitler comparison, particularly today when Israel's military dominance is undeniable and international support for its existence is strong, is being used to demonise a people whose land Israel is occupying and confiscating in the pursuit of its goal of gaining control over the whole of Mandate Palestine, to justify these processes, and to silence critics. Domination and not emancipation is thus the purpose and outcome of the Holocaust-Hitler comparison.

Indeed, it might be more accurate to classify the Holocaust-Hitler comparison as a metaphor rather than an analogy, if we refer back to the earlier distinction between the two as rhetorical devices in the "making of meaning". A metaphor borrows understandings created in one context to "bring meaning" to another context, and allows us to 'see' things we would otherwise not see. For Jewish-Israelis (and indeed Jewish communities worldwide), reference to the Holocaust or Hitler is a powerful rhetorical device that invokes a painful and devastating collective historical memory. Its use ensures cohesion and has created a sense of existential crisis because this was the worst historical experience of persecution for the Jewish people. But Palestinians are not to blame for the Holocaust and so in the context of the Israel-Palestine conflict, "the trauma drama of the Holocaust is a recipe for conflict without end" (Alexander and

${ }^{5}$ I am grateful to Sai Englert for this point. 
Dromi, 2011, p. 31). Indeed, Avraham Burg (quoted in Alexander and Dromi, 2011, p. 10), once Speaker of the Knesset and former chairman of both the World Zionist Organization and the Israeli Jewish Agency, blames "Holocaust consciousness" for the fact that Israelis are not "sensitive enough to what happens to others and in many ways are too indifferent to the suffering of others." Furthermore, there is not a consensus on its use; many Jews, both in Israel and internationally, invoke the Holocaust-Hitler comparison to criticise Israel's actions against Palestinians.

The year 2018 was a significant anniversary year - for both Israel and Palestinians. It marked 70 years since the establishment of the State of Israel and the Nakba, and 50 years of Israel's occupation of the West Bank and Gaza. It is clear that Palestinians and their supporters invoke the comparison with apartheid South Africa as a way to understand their circumstances, connect their experience and struggle with others, and to mobilise internationally for an end to their oppression and dispossession. The social effects of the apartheid comparison are therefore potentially significant. The period of the Oslo peace process (1993-2000) saw a relative hiatus in the use of the apartheid comparison while talks took place and optimism drove beliefs in co-existence. Its resurrection has taken place in an era when peace talks have collapsed and Israel continues to occupy and colonise the (already truncated) geographical space supposed to house a Palestinian state. The re-emergence of the analogy has thus gathered support over the past 15 years as civil society activists and opinion-formers seek to resurrect a movement for Palestinian liberation in the context of an internationally sponsored framework that has only delivered peace to one side.

Even supporters of Israel warn that its rule over Palestinians has 'apartheid-like' features. According to Benjamin Pogrund (2014, p. 133-139), a former deputy editor of the South African newspaper the Rand Daily Mail (which was closed down because of its stand against apartheid, and Pogrund was frequently on trial for his views), inside the 'Green Line' Palestinians face discrimination but not apartheid, while inside the OPT Palestinians face colonial practices and tyranny. However, argues Pogrund, while the two-state solution remains the official stance of Israel, Palestine and the international community, then it is not apartheid. But he concludes that if Jewish-Israeli settlement expansion continues and no Palestinian state comes into existence, and if Israel annexes the West Bank and further enforces separation and discrimination, then what will exist thereafter will be apartheid (2014, p. 139-152). This conclusion seems no different from what Palestinian activists have said, nor figures such as Carter, Kerry, Dugard and Falk, i.e. that there are apartheid-like features of Israel's rule over Palestinians that will soon step over the threshold into a full-blown apartheid system.

What is crucial to note, though, is that the crime of apartheid (like the crime of genocide) has been defined and codified in international law and so strict comparisons with its specific South African experience are not helpful for assessing its legitimacy in the context of the OPT. It is possible, therefore, to conclude that the apartheid comparison should be regarded as a legitimate analogy in that it captures an "essence" of the reality that Palestinians experience. If international legal opinion eventually agrees with this conclusion and charges Israel with the crime of apartheid, the consequences will be significant. The use of the analogy is consequently an important legal strategy for Palestinians (and their supporters) as they press their claims for selfdetermination, especially in the absence of other avenues to achieve their goals. The 
use of such a comparison in this context is therefore highly significant as it has the potential to influence whether Palestinians continue to face dispossession and oppression or whether they gain their emancipation.

\section{Acknowledgements}

I would like to thank the editors of this special issue, Bruno Charbonneau and Adam Sandor, for putting it together. I am also extremely grateful to Rimona Afana, Sai Englert, Dan FreemanMaloy, Toufic Haddad, Nadim Khoury, Michael Pugh, Elian Weizman, and the two anonymous peer reviewers, for incisive comments on an earlier draft. However, all perspectives and errors are my responsibility.

\section{Declaration of interest statement}

There was no conflict of interest involved in the research, writing or publication of this article.

\section{Bibliography}

Achcar, G., 2010. The Arabs and the Holocaust: The Arab-Israeli war of narratives. London: Saqi Books.

Akrivoulis, D.E., 2015. Metaphors matter: the ideological functions of the Kosovo-Holocaust analogy, Journal of Balkan and Near Eastern Studies, 17 (2), 222-242.

Alexander, J.C., and Dromi, S.M., 2011. Trauma construction and moral restriction. In: R. Eyerman, J.C. Alexander and E. Breese, eds. Narrating trauma: on the impact of collective suff ering. Boulder, CO: Paradigm Publishers, 107-132.

Aljazeera, 2017. Israel's volunteer soldiers. AlJazeera. Available from: http://www.aljazeera.com/ programmes/aljazeeraworld/2017/08/israel-volunteer-soldiers-170814073507910.html

Apple, R. W., 2001. Afghanistan as Vietnam, New York Times, 31 October.

Barghouti, O., 2011. Boycott, disinvestment and sanctions: the global struggle for Palestinian rights, Haymarket: Chicago.

Berlin, E.B., 2015. Everybody's Holocaust. Jerusalem Post, 15 May. Available from: https://www.jpost.com/Jerusalem-Report/Everybodys-Holocaust

Chandler, A., 2015. Germany clarifies: we're responsible for the Holocaust, The Atlantic, 21 October. Available from: https://www.theatlantic.com/international/archive/2015/10/holocaustisrael-netanyahu-palestinians-jews/411703/

Clarno, A., 2017. Neoliberal Apartheid: Palestine/Israel and South Africa after 1994. University of Chicago Press. 
Dodge, T., Enemy images, coercive socio-engineering and civil war in Iraq. In M. Turner and F. Kuehn, eds. The politics of international intervention: the tyranny of peace, Abingdon:

Routledge, 197-217.

Desch, M.C., 2006. The myth of abandonment: the use and abuse of the Holocaust analogy, Security Studies, 15 (1), 106-145.

Davis, U., 1987. Apartheid Israel: possibilities for the struggle within. London: Zed Books.

Dershowitz, A.M., 2010. Bishop Tutu is no saint when it comes to Jews, Gatestone Institute, 20 December. Available from:https://www.gatestoneinstitute.org/1742/bishop-tutu-is-no-saintwhen-it-comes-to-jews

Dugard, J., 2007. Report of the Special Rapporteur on the situation of human rights in the Palestinian territories occupied since 1967. 29 January, UN Human Rights Council, $\mathrm{A} / \mathrm{HRC} / 4 / 17$.

Dugard, J., and Reynolds, J., 2013. Apartheid, international law, and the Occupied Palestinian Territory, The European Journal of International Law 24 (3), 867-913.

Englert, S., 2018. Judaism, Zionism and the Nazi genocide: Jewish identify formation in the west between assimilation and rejection. Historical Materialism, 26 (2). Available from: http://www.historicalmaterialism.org/articles/judaism-zionism-and-nazi-genocide

Fairclough, N., 1995. Critical discourse analysis: the critical study of language. Routledge.

Fairclough, N., Jessop, B., and Sayer, A., 2002. Critical realism and semiosis. Department of Sociology, Lancaster University.

Fairclough, N., 2003. Analysing discourse: textual analysis for social research. Routledge.

Falk, R., 2010. Report of the Special Rapporteur on the situation of human rights in the Palestinian territories occupied since 1967, 30 August, UN Human Rights Council, A/HRC/65/331.

Feld, M.N., 2013. Israeli apartheid: our South Africa moment: review. Journal of the Society for Contemporary Thought and the Islamicate World, 27 September.

Finkelstein, N., 2000. The Holocaust industry: reflections on the exploitation of Jewish suffering. London: Verso.

Gordon, N., 2018. The 'new anti-Semitism', 4 January, London Review of Books 40 (1), 18. Available from: https://www.lrb.co.uk/v40/n01/neve-gordon/the-new-anti-semitism

Gur-Ze'ev, I., 2000. Defeating the enemy within: exploring the link between Holocaust education and the Arab/Israeli conflict. Religious Education 95 (4), 373-401. 
Hofstadter, D., 1995. A review of mental leaps: analogy in creative thought, Magazine of the American Association for Artificial Intelligence, Fall, 75-80.

Human Sciences Research Council of South Africa, 2009. Occupation, colonialism, apartheid? A re-assessment of Israel's practices in the occupied Palestinian territories under international law. Cape Town. Available from:

http://www.alhaq.org/attachments/article/236/Occupation_Colonialism_Apartheid-FullStudy.pdf

Israeli Apartheid Week, Website, http://apartheidweek.org/

IDF, 2014. The soldier-guides of the Holocaust Museum Yad Vashem, IDF Blog, 29 April. Available from: https://www.idfblog.com/2014/04/29/soldier-guides-holocaust-museum-yadvashem.

Israel Defense Forces, no date. Tag: witnesses in uniform, Israel Defense Forces. Available from: https://www.fidf.org/how-we-help/education/witnesses-uniform. Accessed 6 June 2018.

Jacobs, S., and Soske, J., eds, 2015. Apartheid Israel: the politics of an analogy, Haymarket.

Johnston, A., 2007. UN envoy hits Israel 'apartheid'. BBC News, 23 February. Available from: http://news.bbc.co.uk/2/hi/middle_east/6390755.stm

Kasrils, R., 2015. Birds of a feather: Israel and apartheid South Africa - colonialism of a special type. In: Pappe, I., ed. Israel and South Africa: The Many Faces of Apartheid. Zed Books, 2342.

Khong, Y.F., 1992. Analogies at war: Korea, Munich, Dien Bien Phu, and the Vietnam decisions of 1965, Princeton University Press.

Klar, Y., Schori-Eya, N., and Klar, Y., 2013. The 'never again' state of Israel: the emergence of the Holocaust as a core feature of Israeli identity and its four incongruent voices, Journal of Social Issues, 69 (1), 125-143.

Knopf-Newman, M.J., 2011. The politics of teaching Palestine to Americans: addressing pedagogical strategies. PalgraveMacmillan.

Lakoff, G., and Johnson, M., 1980. Metaphors we live by. London: University of Chicago Press.

Litvak, M., and Webman, E., 2009. From empathy to denial: Arab response to the Holocaust, Columbia University Press.

Loshitzky, Y. 2006. Pathologising memory. Third Text, 20 (3-4), 327-335.

Maasen, S., and Weingart, P., 2000. Metaphors and the dynamics of knowledge, New York: Routledge. 
Magal, T., Bar-Tal, D., and Halperin, E., 2016. Why is it so difficult to resolve the IsraeliPalestinian conflict by Jews? a socio-psychological approach. In E. Ben-Rafael, J.H. Schoeps, Y. Sternberg, and O. Glöckner eds. Handbook of Israel: the major debates. De Gruyter.

Massad, J. A., 2006. The persistence of the Palestinian question: essays on Zionism and the Palestinians, Abingdon: Routledge.

McCarthy, R., 2007. Israel risks apartheid-like struggle if two-state solution fails, says Olmert. The Guardian, 30 November. Available from:

https://www.theguardian.com/world/2007/nov/30/israel.

McGreal, C. 2006a. Worlds apart. The Guardian, 6 February. Available from: https://www.theguardian.com/world/2006/feb/06/southafrica.israel

McGreal, C., 2006b, Brothers in arms: Israel's secret pact with Pretoria, The Guardian, 7 February. Available from: https://www.theguardian.com/world/2006/feb/07/southafrica.israel.

Mendel, Y., A new nationalistic political grammar: Jewish-Israeli society 25 years after Oslo. In: M. Turner, ed. From the River to the Sea: Palestine and Israel in the Shadow of 'Peace', Lanham: Rowman and Littlefield, 2019, 159-177.

Miller, P.D., 2016. Graveyard of analogies: the use and abuse of history for the war in Afghanistan, Journal of Strategic Studies 39 (3), 446-476.

Myre, G., 2003. Man in the news: soft-spoken but not afraid to air views, Mahmoud Abbas. New York Times, 11 March. Available from: https://www.nytimes.com/2003/03/11/world/man-in-thenews-soft-spoken-but-not-afraid-to-voice-opinions-mahmoud-abbas.html

Normand, L., 2016. Demonization in international politics: a barrier to peace in the IsraelPalestine conflict. PalgraveMacmillan.

Novick, P., 1999. The Holocaust in American life. Boston: Houghton Mifflin.

Ochs, J., 2006. The politics of victimhood and its internal exegetes: terror victims in Israel, History and Anthropology, 17 (4), 355-368.

Pappe, I., 2007. Clusters of history: US involvement in the Palestine question. Race \& Class, 48 (3), 1-28.

Parker, S., 2015 'Unwanted invader': The representation of refugees and asylum seekers in the UK and Australian print media, eSharp, Issue 23: 'Myth and Nation'. Available from:

http://www.gla.ac.uk/media/media_404384_en.pdf;

Pileggi, T., 2015. Netanyahu blasts Abbas's 'deceitful' UN speech, Times of Israel, 30

September. Available from:

http://www.timesofisrael.com/netanyahu-blasts-abbass-deceitful-un-speech/. 
Pogrund, B., 2014. Drawing fire: investigating the accusations of apartheid in Israel. Lanham: Rowman and Littlefield.

Prime Minister of Israel's Office, 2015. PM Netanyahu's speech at the 37th Zionist Congress 20 October, Jerusalem: Government of Israel. Available from: http://www.pmo.gov.il/English/MediaCenter/Speeches/Pages/speechcongress201015.aspx

Prusher, I., 2013. Mandela was critical of occupation, but fully endorsed Israel's right to exist. Haaretz, 9 December. Available from: https://www.haaretz.com/blogs/jerusalemvivendi/.premium-1.562566

Raved, A., 2015. Historians, politicians slam PM's 'distortion of history', YNet, 21 October. Available from: http://www.ynetnews.com/articles/0,7340,L-4714313,00.html

Rodinson, M., 1973. Israel: a settler colonial state? Pathfinder Press.

Segev, T., 2000. The seventh million: the Israelis and the Holocaust. New York: Henry Holt.

Shariatmadari, D., 2015. Swarms, floods and marauders: the toxic metaphors of the migration, The Guardian, 10 August. Available from: https://www.theguardian.com/ commentisfree/2015/aug/10/migration-debate-metaphors-swarms-floods-marauders-migrants.

Shimoni, G., 2007. Deconstructing apartheid accusations against Israel. Jerusalem Center for Public Diplomacy, 2 September. Available from: http://jcpa.org/article/deconstructing-apartheidaccusations-against-israel/.

Sommer, A.K., 2017. Ehud Barak warns: Israel faces 'slippery slope' toward apartheid. Haaretz, 21 June. Available from: http://www.haaretz.com/israel-news/1.796949

Times of Israel, 2015. Full text of Abbas's 2015 address to the UN General Assembly. The Times of Israel, 30 September. Available from: http://www.timesofisrael.com/full-text-of-abbas2015-address-to-the-un-general-assembly/.

Times of Israel and AFP, 2015. US slams Abbas's 'genocide' UN speech as 'offensive', Times of Israel, 27 September. Available from: http://www.timesofisrael.com/us-slams-abbas-un-speechas-offensive/

Times of Israel, 2015. Livni: We face South Africa-style isolation because of settlements. Times of Israel, 18 January. Available from:

https://www.timesofisrael.com/livni-we-face-south-africa-style-isolation-because-of-settlements/

Turner, M., 2019. Richard Falk: "citizen-pilgrim" in the role of UN Special Rapporteur. Journal of Palestine Studies 48, 59-78.

Tutu, D., 2002. Apartheid in the Holy Land. The Guardian, 29 April. Available from: https://www.theguardian.com/world/2002/apr/29/comment. 
Tutu, D., 2012. Justice requires action to stop subjugation of Palestinians. Tampa Bay Times, 30 April. Available from:

http://www.tampabay.com/opinion/columns/justice-requires-action-to-stop-subjugation-ofpalestinians/1227722;

United Nations, 2002. Rome Statute of the International Criminal Court, Part 2, Article 7. Available from: http://legal.un.org/icc/statute/99_corr/2.htm

Zertal, I., 2005. Israel's Holocaust and the politics of nationhood. Cambridge: Cambridge University Press. 